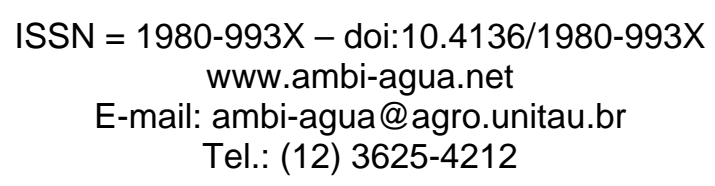

\title{
In vitro effects of petroleum refinery wastewater on dehydrogenase activity in marine bacterial strains \\ (doi:10.4136/ambi-agua.133)
}

\author{
Christopher E. Nwanyanwu ${ }^{1}$; Gideon O. $\mathrm{Abu}^{2}$ \\ ${ }^{1}$ Department of Microbiology, Federal University of Technology, P.M.B.1526, Owerri, Imo State, Nigeria \\ E-mail: cnwanyanwu2000@yahoo.com \\ ${ }^{2}$ Department of Microbiology, University of Port Harcourt, P.M.B.5323, Port Harcourt, Rivers State, Nigeria \\ E-mail: gideonabu1@yahoo.com
}

\begin{abstract}
Toxicity of oil refinery effluent on four bacteria strains isolated from refinery effluent impacted river water sample was assessed via dehydrogenase assay. Pure cultures of the bacterial strains were exposed to various effluent concentrations $[12.5-100 \%(\mathrm{v} / \mathrm{v})]$ in a nutrient broth amended with glucose and TTC. The response of the bacterial strains to refinery effluent is concentration-dependent. At $12.5 \%(\mathrm{v} / \mathrm{v})$, the effluent stimulated dehydrogenase activity in Streptococcus sp. RW3 and Pseudomonas sp. RW4. In all strains, dehydrogenase activity was progressively inhibited at concentrations greater than $12.5 \%(\mathrm{v} / \mathrm{v})$. The $\mathrm{IC}_{50}$ ranges from $25.46 \pm 4.75$ to $31.30 \pm 2.63 \%(\mathrm{v} / \mathrm{v})$. The result of the in vitro study indicated that the bacterial strains are sensitive to oil refinery raw wastewater stress. Therefore, the improperly treated effluent when discharged would pose serious threat to the metabolism of the bacterial strains in natural environments.
\end{abstract}

Keywords: Refinery effluent; toxicity; marine bacteria; dehydrogenase.

\section{Efeitos in vitro de efluentes de refinaria de petróleo em atividade de desidrogenase de cepas de bactérias marinhas}

\section{RESUMO}

A toxicidade de efluentes de refinaria de petróleo em quatro linhagens de bactérias isoladas de amostras de água que sofreram influência de efluente de rio refinaria foi avaliada por meio de ensaio de desidrogenase. Culturas puras das estirpes bacterianas foram expostas a diferentes concentrações de efluentes [12,5-100\% (v/v) em uma amostra de nutrientes alterada com glicose e TTC. A resposta das cepas bacterianas a efluentes de refinaria é dependente da concentração. A atividade de desidrogenase de efluentes com concentração de $12,5 \%$ (v/v) foi estimulada em culturas de Streptococcus sp. RW3 e Pseudomonas sp. RW4. Em todas as estirpes, a atividade de desidrogenase foi progressivamente inibida em concentrações superiores a 12,5\% (v/v). O IC50 variou de 25,46 $\pm 4,75-31,30 \pm 2,63 \%(\mathrm{v} / \mathrm{v})$. $\mathrm{O}$ resultado do estudo in vitro indicou que as bactérias são sensíveis ao stress de efluente bruto de refinaria de petróleo. Portanto, a descarga de efluentes com tratamento inadequado representa uma ameaça grave para o metabolismo das bactérias em ambientes naturais.

Palavras-chave: Toxicidade de efluente de refinaria; bactérias marinhas; desidrogenase.

\section{INTRODUCTION}

Water as resource for life on earth, has several unique properties that help make it such a necessary part of the environment. For example, the entire essential functions within living cells are maintained by water. Water ecosystems are as varied as their individual sites because 
NWANYANWU, C. E.; ABU, G. O. In vitro effects of petroleum refinery wastewater on dehydrogenase activity in marine bacterial strains. Ambi-Agua, Taubaté, v. 5, n. 2, p. 21-29, 2010. (doi:10.4136/ambiagua.133)

they are influenced not only by characteristic local climate, soil, resident communities but also by the surrounding terrestrial ecosystem. As man advances in technology and industry, large amounts of water are used for industrial activities and consequently significant volumes of wastewaters are generated. Based on the type of industry, various levels of pollutants are deliberately released and discharged into the environment directly. Among these industries that discharge their effluents into the aquatic environments are the petroleum oil refineries. As not all refineries have the same processes, the effluents that are produced will have different chemical compositions depending on the type of treatment they received (Wake, 2005; Hernandez et al., 1998; Lehtinen, 1986). Wastewaters released by oil refineries contain large amounts of toxic derivatives such as oil and grease, phenols, sulphides, cyanides, suspended solids, nitrogen compounds as well as heavy metals such as iron, nickel, copper, selenium, zinc, molybdenum, etc. (Burks, 1982). Due to the ineffectiveness of purification systems, wastewaters from the refineries may become seriously dangerous, leading to the accumulation of toxic products in the receiving water bodies with potentially serious consequences on the ecosystem (Otokunefor and Obiukwu, 2005). Thus the discharge of these effluents containing persistent chemicals into a receiving waterbody may result in the long term effects to aquatic biota (Tisler et al., 1999). The toxicity of oil refinery effluents to aquatic organisms has being reported in many literatures. Toxicity of petroleum refinery depends on a number of factors which include quantity, volume and variability of discharge. The different components of the effluents may have varying effects and toxicity (Saha and Konar, 1985). Aruldoss and Viraraghavan (1998) reported the toxicity of refinery wastewater to luminescent bacteria (Photobacterium phosphoreum) using microtox in the bioassay. This is based on monitoring changes in natural light emissions from the organism. Toxicity and end point was measured as the effective concentration of a test sample that can cause $50 \%$ decrease in light out $\left(\mathrm{IC}^{50}\right)$ after $30 \mathrm{~min}$ of contact time.

Microorganisms are vital for the efficient functioning of any ecosystem; hence factors that affect their metabolism, composition and abundance are of great concern. Monitoring microbial responses has been recommended as an early warning indicator of ecosystem stress as microbes respond promptly to environmental perturbations (Nweke et al., 2007; Griffiths, 1983). Measurement of microbial enzyme activity is used in the assessment of ecotoxicological impacts of environmental substrates. In this regard, dehydrogenase activity has been widely used. The dehydrogenase assay is an effective primary test for assessing the potential toxicity of chemicals to microbial activities (Ghaly and Mahmoud, 2006; Griebe et al., 1997). In this assessment, dehydrogenase activity (DHA) is measured using the reduction of 2, 3, 5-triphenyltetrazolium chloride (TTC) to triphenylformazan (TPF). Determination of their ability to reduce TTC to the formazan product after exposure to test compounds, compared to the control situation, enables the relative toxicity of the chemicals to be assessed.

This study was aimed at assessing the in vitro effects of petroleum refinery wastewater on the dehydrogenase activity in bacterial species isolated from refinery effluent impacted Okrika River water in Port Harcourt, Nigeria.

\section{MATERIALS AND METHODS}

\subsection{Characterization of petroleum oil refinery wastewater}

Composite mechanically (gravity separation that include API separators and tank separation) and physicochemically (addition of additives, flocculation, sedimentation and filtration) pretreated petroleum oil refinery wastewater was collected at the inlet to the biological treatment unit (Rotary biodisk) at the Port Harcourt oil refinery complex using 5 litres polyethylene containers. The containers were rinsed several times with the effluent sample at the point of collection. The samples were taken to the laboratory in icebox within 
NWANYANWU, C. E.; ABU, G. O. In vitro effects of petroleum refinery wastewater on dehydrogenase activity in marine bacterial strains. Ambi-Agua, Taubaté, v. 5, n. 2, p. 21-29, 2010. (doi:10.4136/ambiagua.133)

$6 \mathrm{~h}$ of collection. Phenol concentration, $\mathrm{pH}, \mathrm{COD}, \mathrm{BOD}, \mathrm{THC}$, cations $\left(\mathrm{Pb}^{3+}\right.$ and $\left.\mathrm{Cu}^{2+}\right)$ and anions $\left(\mathrm{PO}_{4}{ }^{2+}\right.$ and $\mathrm{Cl}-$ ) in wastewater samples were determined according to standard methods (APHA, 1998).

\subsection{Bacterial strains and culture conditions}

The bacterial strains used in these studies were isolated from water samples collected from oil refinery effluent-impacted Okrika river water samples located in Port Harcourt, Nigeria.

The isolates - Citrobacter sp. RW1, Staphylococcus sp. RW2, Streptococcus sp. RW3, Pseudomonas sp. RW4 were purified on nutrient agar (Fluka) plates and characterizations were done using standard microbiological methods. Identifications to the genus level followed the schemes of Holt et al. (1994). The isolates were maintained and sub-cultured once in every month in a basal minimal medium containing (per liter): ammonium chloride 10 g, ammonium nitrate $4.0 \mathrm{~g}, \mathrm{~K}_{2} \mathrm{HPO}_{4} 0.2 \mathrm{~g}, \mathrm{KH}_{2} \mathrm{PO}_{4} 0.8 \mathrm{~g}, \mathrm{MgSO}_{4} 0.1 \mathrm{~g}$; phenol as the sole carbon and energy source. The $\mathrm{pH}$ was adjusted to 8.0 using phosphate buffers.

The bacterial strains were grown to mid exponential phase in nutrient broth (Lab M) on a rotary incubator (Stuart, ST150SA, UK, $150 \mathrm{rpm})$ at room temperature $\left(28 \pm 2^{\circ} \mathrm{C}\right)$. The cells were harvested by centrifugation at $8000 \mathrm{rpm}$ for $10 \mathrm{~min}$. Harvested cells were washed twice in deionised distilled water and re-suspended in the same deionized distilled water. The resuspended cells were standardized in a spectrophotometer to an optical density of 0.90 at $540 \mathrm{~nm}$. The dry weight of the standardized cells was determined by drying $15 \mathrm{ml}$ of the cell suspension to constant weight in an oven (Gallenkamp, England) at $110^{\circ} \mathrm{C}$. The standardized cell suspensions were used as inoculum in the dehydrogenase activity assay.

\subsection{Dehydrogenase activity assay}

Dehydrogenase assay method as described by Nweke et al. (2007) was employed with little modification. Briefly, dehydrogenase activity was determined using TTC (BDH England) as the artificial electron acceptor, which was reduced to the red-coloured triphenyl formazan (TPF). The assay was done in $3.5 \mathrm{ml}$ volumes of nutrient broth-glucose-TTC medium supplemented with varying concentrations $[0-100 \%(\mathrm{v} / \mathrm{v})]$ of oil refinery wastewater in separate $20 \mathrm{ml}$ screw-capped test tubes. Aliquots $(0.2 \mathrm{ml})$ of the bacterial suspensions were inoculated into triplicate glass tubes containing $2.5 \mathrm{ml}$ of nutrient brothglucose medium amended with graded concentrations of oil refinery wastewater that was diluted with $0.7 \mathrm{ml}$ deionized distilled water and preincubated on a rotary incubator $(150 \mathrm{rpm})$ at room temperature $\left(28 \pm 2^{\circ} \mathrm{C}\right)$ for $60 \mathrm{~min}$. Thereafter, $0.1 \mathrm{ml}$ of $0.1 \%(\mathrm{v} / \mathrm{v}) \mathrm{TTC}$ in deionised distilled water were added to each tube to obtain final effluent concentrations of 0 , $12.5,25,50,75,100 \%(\mathrm{v} / \mathrm{v})$ in different test tubes. The final concentrations of nutrient broth, glucose and TTC in the medium were 2,2 and $0.267 \mathrm{mg} / \mathrm{ml}$, respectively. The controls consisted of the isolates and the media without wastewater. The reaction mixtures were further incubated statically at room temperature $\left(28 \pm 2^{\circ} \mathrm{C}\right)$ for $6 \mathrm{~h}$. The TPF produced was extracted in $4 \mathrm{ml}$ of amyl alcohol and determined spectrophotometrically at $445 \mathrm{~nm}$ ( $\lambda \max )$. The amount of formazan produced was determined from a standard dose-response curve [0 $20 \mu \mathrm{g} / \mathrm{ml}$ TPF (Sigma) in amyl alcohol; $\left.\mathrm{y}=0.0484 \mathrm{x} ; \mathrm{R}^{2}=0.9958\right]$. Dehydrogenase activity was expressed as milligrams of TPF formed per mg dry weight of cell biomass per hour. Inhibition of dehydrogenase activity in the isolates by wastewater was calculated relative to the control. The percentage inhibitions for bacterial strains were linearized against the concentrations of the refinery wastewater using gamma parameter $(\Gamma)[\Gamma=\%$ Inhibition / $(100$ - \%Inhibition)] (Tarkpea et al., 1986). The toxicity threshold concentrations (IC ${ }^{50}$ ) which is an inhibitory concentration of toxicant required to reduce $50 \%$ of the dehydrogenase activity were then determined from the linear regression plots. 
NWANYANWU, C. E.; ABU, G. O. In vitro effects of petroleum refinery wastewater on dehydrogenase activity in marine bacterial strains. Ambi-Agua, Taubaté, v. 5, n. 2, p. 21-29, 2010. (doi:10.4136/ambiagua.133)

\subsection{Statistical analysis}

Data obtained from the study were analyzed by the use of two-way analysis of variance (ANOVA) and values for $P<0.05$ were considered statistically significant.

\section{RESULTS AND DISCUSSION}

The results of the chemical characterization of the oil refinery wastewater sample are shown in Table 1. The Wastewater sample had elevated levels of organic compounds as indicated by the concentrations of COD BOD, THC and phenol as all measured values exceed the FEPA permissible limit values (Table 1). The bacterial strains were able to reduce TTC to its formazan and so were used to assess toxicity of refinery wastewater through the dehydrogenase assay.

The dehydrogenase activity (DHA) varied among the bacterial strains (Table 2). The Gram-negative strains of Pseudomonas sp. and Citrobacter sp. have higher rate of dehydrogenase

Table 1. Characteristics of petroleum oil refinery wastewater.

\begin{tabular}{l|c|c}
\hline Parameter/unit & $\begin{array}{c}\text { Refinery } \\
\text { wastewater }\end{array}$ & $\begin{array}{c}\text { FEPA wastewater } \\
\text { limitations Guideline } \\
(\mathbf{1 9 9 1})\end{array}$ \\
\hline $\mathrm{pH}$ & 7.64 & $6.0-9.0$ \\
$\mathrm{THC}(\mathrm{mg} / \mathrm{l})$ & 17.5 & 10.0 \\
$\mathrm{TDS}(\mathrm{mg} / \mathrm{l})$ & 950 & 2000.0 \\
$\mathrm{BOD}(\mathrm{mg} / \mathrm{l})$ & 32.0 & 10.0 \\
$\mathrm{COD}(\mathrm{mg} / \mathrm{l})$ & 112 & 40.0 \\
Phenol (mg/l) & 71.2 & 0.05 \\
Phosphate (mg/l) & 0.22 & 5.0 \\
Chloride (mg/l) & 44.0 & 600.0 \\
Lead (mg/l) & $<0.01$ & 0.5 \\
Copper (mg/l) & $<0.01$ & 1.0 \\
\hline
\end{tabular}

Table 2. Uninhibited dehydrogenase activities in the isolates.

\begin{tabular}{l|c}
\hline \multicolumn{1}{c|}{ Bacterial Strain } & $\begin{array}{c}\text { Dehydrogenase activity } \\
(\boldsymbol{\mu g} \text { Formazan/mg cell dry weight/h) }\end{array}$ \\
\hline Citrobacter sp. RW1 & $0.452 \pm 0.011$ \\
Staphylococcus sp. RW2 & $0.433 \pm 0.012$ \\
Streptococcus sp. RW3 & $0.448 \pm 0.012$ \\
Pseudomonas sp. RW4 & $0.467 \pm 0.011$ \\
\hline
\end{tabular}

activity than the Gram-positive strains of Staphylococcus sp. and Streptococcus sp. This is in agreement with Nweke et al. (2007) and Nwogu et al. (2007) in which the Gram-negative organisms (Pseudomonas species isolated from the environment and human sources respectively) had higher dehydrogenase activity than gram-positive organisms. Earlier report (Alisi et al., 2008) is however at variance with this observation. These variations may be due to differences in bacterial physiology, including cell wall components or dehydrogenase systems, since different microorganisms have been reported to have different dehydrogenase systems (Praveen-Kumar, 2003).

The effects of the different concentrations of the effluent on the bacterial isolates with respect to inhibition and dehydrogenase activity are shown in Figures 1 and 2. The responses of the bacterial dehydrogenase activities to the refinery effluent are concentration-dependent and vary among the organisms. For Citrobacter sp. RW1 and Staphylococcus sp. RW2, 
NWANYANWU, C. E.; ABU, G. O. In vitro effects of petroleum refinery wastewater on dehydrogenase activity in marine bacterial strains. Ambi-Agua, Taubaté, v. 5, n. 2, p. 21-29, 2010. (doi:10.4136/ambiagua.133)

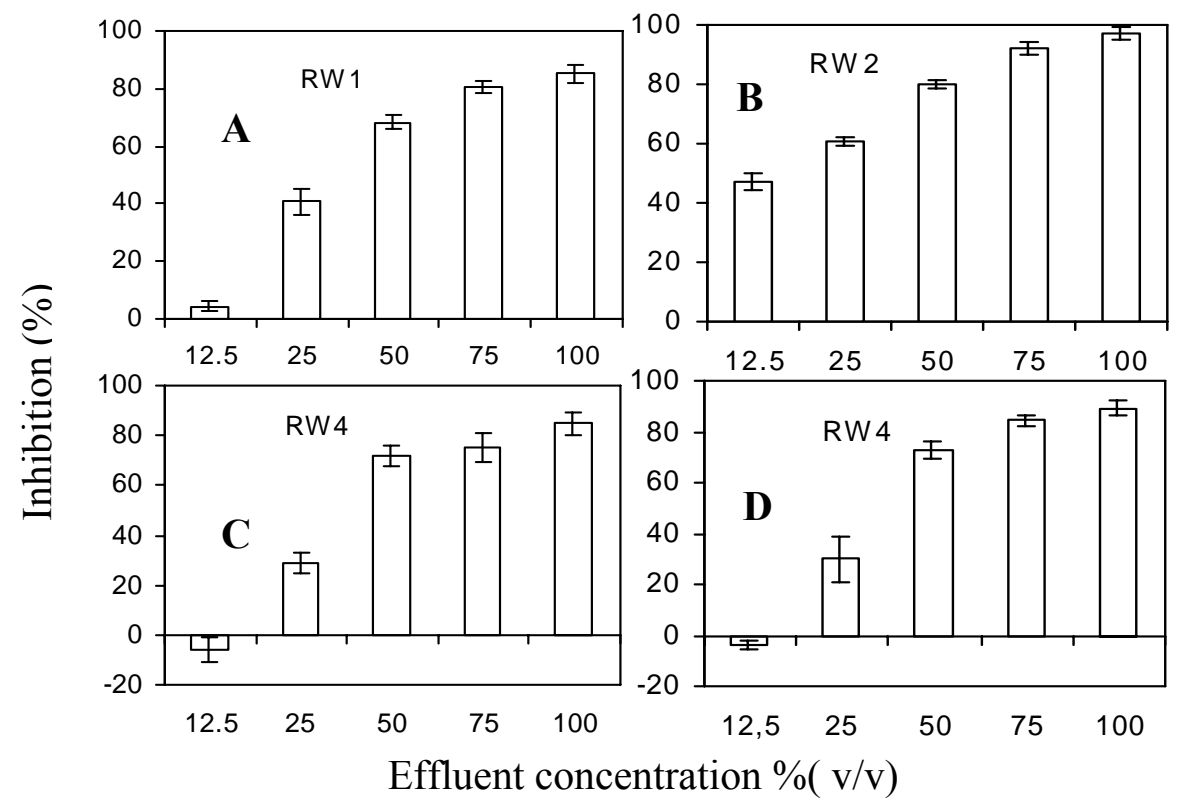

Figure 1. Effluent inhibition of dehydrogenase activity in Citrobacter sp. RW1 (A), Staphylococcus sp. RW2 (B), Streptococcus sp. RW3(C), Pseudomonas sp.RW4 (D).

$(>0 \%=$ Inhibition $;<0 \%=$ Stimulation $)$.

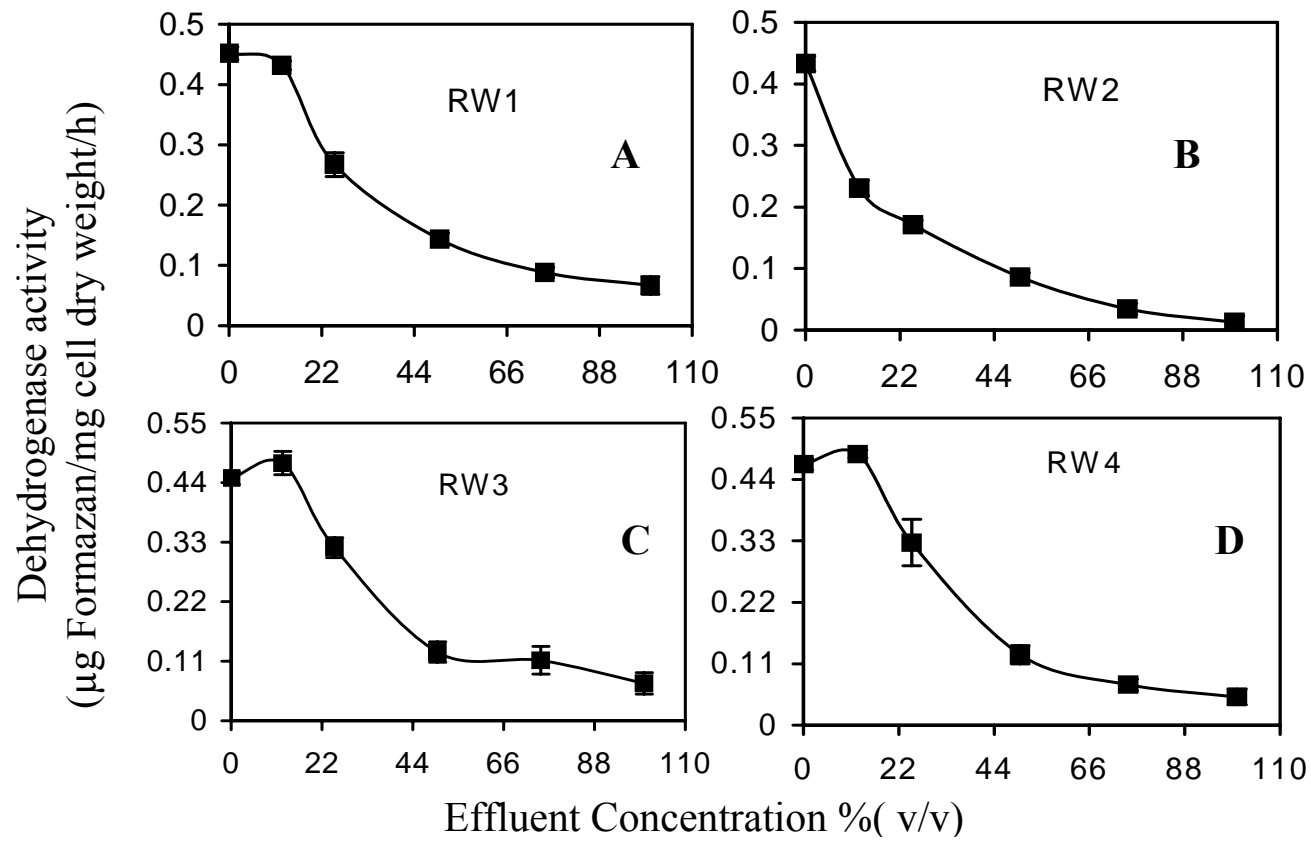

Figure 2. TTC reduction activity in response to different concentration of the refinery effluent by Citrobacter sp. RW1 (A), Staphylococcus sp. RW2 (B), Streptococcus sp. RW3 (C), Pseudomonas sp. RW4 (D). Mean \pm standard deviation $(n=3)$ are indicated by bars. Some standard deviations are within data point. 
NWANYANWU, C. E.; ABU, G. O. In vitro effects of petroleum refinery wastewater on dehydrogenase activity in marine bacterial strains. Ambi-Agua, Taubaté, v. 5, n. 2, p. 21-29, 2010. (doi:10.4136/ambiagua.133)

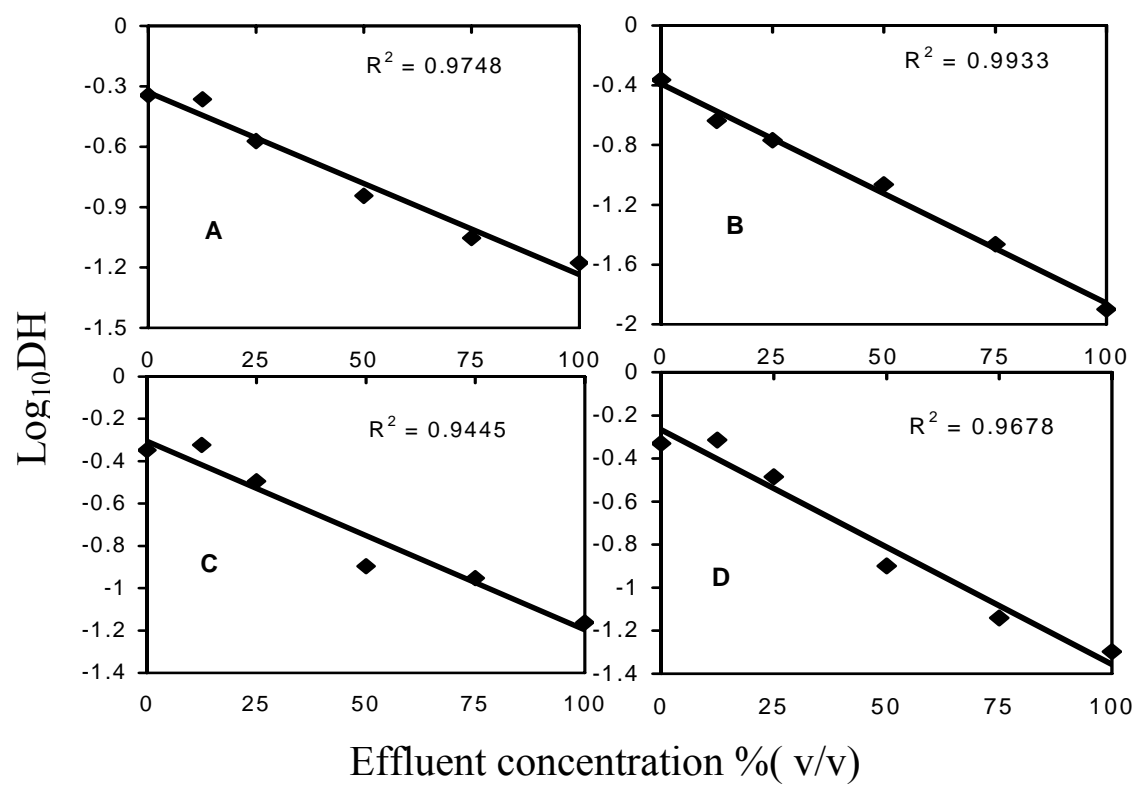

Figure 3. Correlation of effluent concentrations with dehydrogenase activity (DHA) in response to effluent toxicity by Citrobacter sp. RW1 (A), Staphylococcus sp. RW2 (B), Streptococcus sp. RW3 (C), Pseudomonas sp. RW4 (D).
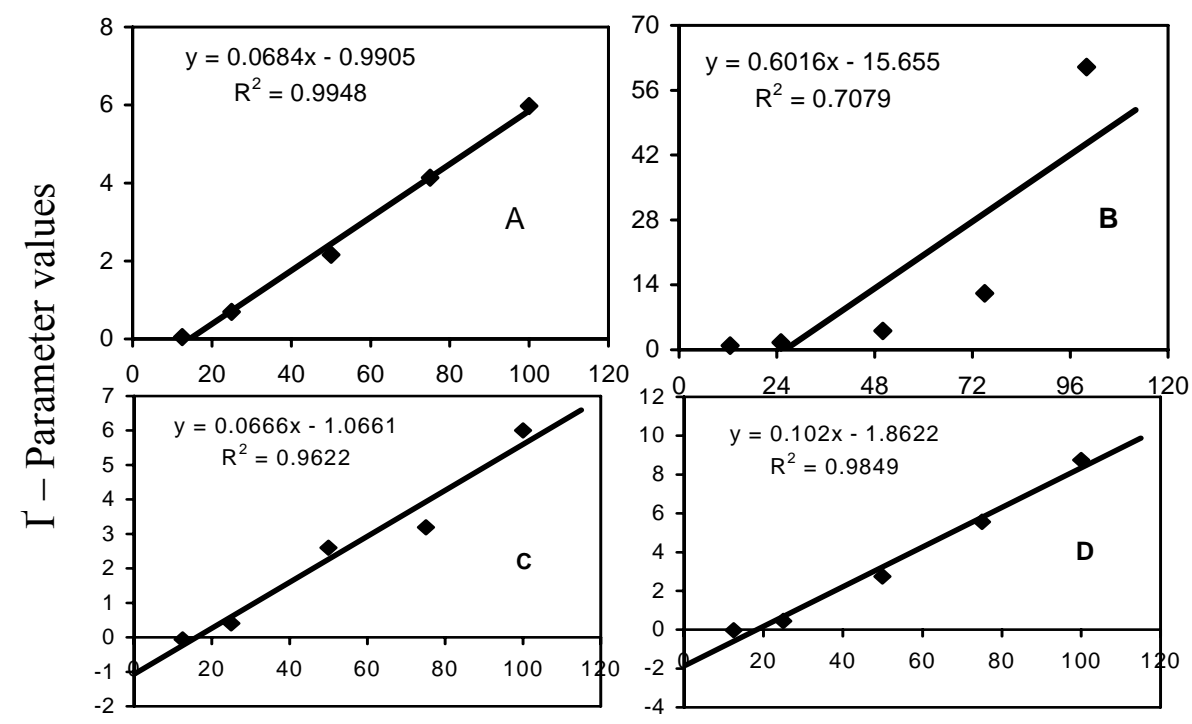

Effluent concentration \%( v/v)

Figure 4. Gamma (I) parameter values of Citrobacter sp. RW1 (A), Staphylococcus sp. RW2 (B), Streptococcus sp. RW3 (C), Pseudomonas sp. RW4 (D) in response to refinery effluent $[0-100 \%(\mathrm{v} / \mathrm{v})]$.

dehydrogenase activity reduced with increasing concentrations of effluent (Figure 2). On the contrary, for Streptococcus sp. RW3 and Pseudomonas sp. RW4, dehydrogenase activities were stimulated at $12.5 \%(\mathrm{v} / \mathrm{v})$ and thereafter progressive inhibition was also observed at concentrations above $12.5 \%(\mathrm{v} / \mathrm{v})$. The stimulation of Streptococcus sp. RW3 and Pseudomonas sp. RW4 observed at lower concentration of effluent is attributable to the use of phenols and other inorganic pollutants within the effluents by these bacteria. The inhibition of dehydrogenase activities observed in this study is consistent with the reported toxic effects of 
NWANYANWU, C. E.; ABU, G. O. In vitro effects of petroleum refinery wastewater on dehydrogenase activity in marine bacterial strains. Ambi-Agua, Taubaté, v. 5, n. 2, p. 21-29, 2010. (doi:10.4136/ambiagua.133)

industrial effluents at high concentrations (Tisler et al., 1999; Fountoulakis et al., 2002). Results presented in Figure 1 showed that at lower effluent concentrations $[\leq 25.0 \%(\mathrm{v} / \mathrm{v})]$, Streptococcus sp. RW3 had higher percentage inhibition than other organisms. This implies that Streptococcus sp. RW3 was more sensitive to refinery effluent stress than the other bacterial strains studied. Comparatively, at higher concentrations $[\geq 50.0 \%(\mathrm{v} / \mathrm{v})]$, Pseudomonas sp. RW4 was more tolerant to the refinery effluent than the other bacteria. Different sensitivities of microbes to refinery effluent toxicity could be related to the longterm exposure to toxic components of the effluent by the organism.

Table 3. Threshold inhibitory concentrations of petroleum refinery wastewater against the bacterial strains.

\begin{tabular}{l|c}
\hline Bacterial strain & $\begin{array}{c}\text { Inhibitory concentration }\left(\mathbf{I C}_{\mathbf{5 0}}\right) \\
\mathbf{\%}(\mathbf{v} / \mathbf{v})\end{array}$ \\
\hline Citrobacter sp. RW1 & $29.25 \pm 1.13$ \\
Staphylococcus sp. RW2 & $25.46 \pm 4.75$ \\
\hline Streptococcus sp. RW3 & $31.30 \pm 2.63$ \\
Pseudomonas sp. RW4 & $31.30 \pm 1.71$ \\
\hline
\end{tabular}

Table 4. R2 values of linear regression plots of transformation data of dehydrogenase activity of the bacterial strains.

\begin{tabular}{l|c|c|c}
\hline \multirow{2}{*}{ Regression plot } & \multicolumn{3}{|c}{$\mathbf{R}^{\mathbf{2}}$ - values } \\
\cline { 2 - 4 } & $\begin{array}{c}\mathbf{L o g} \\
\text { dehydrogenase }\end{array}$ & $\begin{array}{c}\text { Inhibition } \\
\mathbf{( \% )}\end{array}$ & I - parameter \\
\hline Citrobacter sp. RW1 & 0.9748 & 0.955 & 0.9948 \\
Staphylococcus sp. RW2 & 0.9933 & 0.940 & 0.7079 \\
Streptococcus sp. RW3 & 0.9445 & 0.8025 & 0.9622 \\
Pseudomonas sp. RW4 & 0.9678 & 0.9630 & 0.9498 \\
\hline
\end{tabular}

The gram-negative Pseudomonas sp. RW4 seems to tolerate the toxicity of the effluent more than the gram-positive Staphylococcus sp. RW2. The evidence is seen from the threshold inhibitory concentration data (Table 3 ). Dehydrogenase activity correlates with effluent concentration as shown in Figure 3. The higher $R^{2}$ values $\left(0.9445 \leq R^{2} \leq 0.9933\right)$ indicate that the concentration was a strong determinant of dehydrogenase activity in the isolates. Thus, the effluent at high concentration exerted serious stress on the organisms. The logarithmic plot of the dehydrogenase activity (Figure 3) and the gamma parameter model (Figure 4) gave good linearization of the dose response data for the bacterial isolates. The high $\mathrm{R}^{2}$ values for the linear regression plots of Log DHA and gamma parameter (Table 4) lays credence to the linear relationship. Gamma parameter models had higher $\mathrm{R}^{2}$ values than the $\%$ inhibition plots (Table 4 ) and hence the linear regression models were used to assess the threshold inhibitory concentration of the effluent on the organism.

The 2-way analysis of variance shows that the dehydrogenase activity and its percentage inhibition varied significantly $(\mathrm{P}<0.05)$ with bacteria strain and effluent concentration. The result of this in vitro study indicated that oil refinery effluent exerts toxic effect against the tested organisms and Gram-positive Staphylococcus sp. was more responsive than the Gramnegative Pseudomonas sp. 
NWANYANWU, C. E.; ABU, G. O. In vitro effects of petroleum refinery wastewater on dehydrogenase activity in marine bacterial strains. Ambi-Agua, Taubaté, v. 5, n. 2, p. 21-29, 2010. (doi:10.4136/ambiagua.133)

\section{CONCLUSIONS}

In all strains, dehydrogenase activity was progressively inhibited at concentrations greater than $12.5 \%(\mathrm{v} / \mathrm{v})$. The $\mathrm{IC}_{50}$ ranges from $25.46 \pm 4.75$ to $31.30 \pm 2.63 \%(\mathrm{v} / \mathrm{v})$. The result of the in vitro study indicated that the bacterial strains are sensitive to oil refinery raw wastewater stress. Therefore, the improperly treated effluent when discharged would pose serious threat to the metabolism of the bacterial strains in natural environments.

\section{REFERENCES}

ALISI, C. S.; NWANYANWU, C. E.; AKUJOBI, C. O.; IBEGBULEM, C. O. Inhibition of dehydrogenase activity in pathogenic bacteria isolates by aqueous extracts of Musa paradisiacal (Var. Sapientum). African Journal of Biotechnology, v. 7, n. 12, p. 1821 $-1825,2008$.

AMERICAN PUBLIC HEALTH ASSOCIATION - APHA. Standard methods for the examination of water and wastewater. 20. ed. Washington: APHA, 1998. p. 5-43.

ARULDOSS, J. A.; VIRARAGHAVAN, T. Toxicity testing of refinery wastewater using microtox. Bull. Environ. Contam. Toxicol., v. 60, p. 456 - 463, 1998.

BURKS, S. L. Review of pollutants in petroleum refinery wastewaters and effect upon aquatic organisms. Environmental International, v. 7. p. 271 - 283, 1982.

FOUNTOULAKIS, M. S.; DOKIANAKIS, S. N.; KORNAROS, M. E.; AGGELIS, G. G.; LYBERATOS, G. Removal of phenolics in olive mill wastewaters using the white-rot fungus Pleurotus ostreatus. Water Research. v. 36, p. 4735 - 4744, 2002.

GHALY, A. E.; MAHMOUD, N. S. Optimum Conditions for Measuring Dehydrogenase activity of Aspergillus niger using TTC. American Journal of Biochemistry and Biotechnology, v. 2, n. 4, p. 186 - 194, 2006.

GRIEBE, T.; SCHAULE, G.; WUERTZ, S. Determination of microbial respiratory and redox activity in activated sludge. Journal of Industrial Microbiology and Biotechnology, v. 19, p. 118-122, 1997.

GRIFFITHS, R. P. The importance of measuring microbial enzymatic functions while assessing and predicting long-term anthropogenic perturbations. Mar. Pollut. Bull., v. 14, p. $162-165,1983$.

HERNANDEZ, A; MELLADO, R. P.; MARTINEZ, J. L. Metal accumulation and vanadiuminduced multidrug resistance by environmental isolates of Escherichia hermanii and Enterobacter cloacae. Appl. Environ. Microbial., v. 64, p. 4317 - 432, 1998.

HOLT, J. G.; KRIEG N. R; SNEATH P. H. A.; STALEY J. T.; WILLIAMS S. T. Bergey's manual of determinative bacteriology. 9. ed. Baltimore: Williams Wilkins, 1994.

LEHTINEN, C. M. Environmental impact studies of refinery effluent: a challenge to the analytical chemist. In: GIAM, C. S.; DOUBY, J. M. (Eds). Strategies and advance techniques for marine pollution studies; Mediterranean Sea. Berlim: Springer Verlag, 1986. p. 315-326. 
NWANYANWU, C. E.; ABU, G. O. In vitro effects of petroleum refinery wastewater on dehydrogenase activity in marine bacterial strains. Ambi-Agua, Taubaté, v. 5, n. 2, p. 21-29, 2010. (doi:10.4136/ambiagua.133)

NWEKE, C. O.; ALISI, C. S.; OKOLO, J.C.; NWANYANWU, C. E. Toxicity of zinc to heterotrophic bacteria from tropical river sediment. Applied Ecology and Environmental Research, v. 5, n. 1, p. 123 - 132, 2007.

NWOGU, L. A.; ALISI, C. S.; IBEGBULEM, C. O.; IGWE, C. U. Phytochemical and antimicrobial activity of ethanolic extract of Landophia owarensis leaf. African Journal of Biotechnology, v. 6, n. 7, p. 890 - 893, 2007.

OTOKUNEFOR, T. V.; OBIUKWU, C. Impact of refinery effluent on the physicochemical properties of a water body in the Niger delta. Applied Ecology and Environmental Research, v. 3, n. 1, p. 61 - 72, 2005.

PRAVEEN-KUMAR, J. C. 2, 3, 5-Triphenyltetrazolium chloride (TTC) and Electron acceptor of culturable cell bacteria, fungi and Actinomycetes. Biology and Fertility Soil, v. 38, p. 186 - 189, 2003.

SAHA, M. K.; KONAR, S. K. Chronic effects of petroleum refinery effluent on aquatic ecosystem. Environmental Ecology, v. 2, p. 262 - 265, 1985.

TARKPEA, M.; HANSSON, M.; SAMUELSSON, B. Comparison of the microtox test with the 96-h LC50 test for the harpactioid Nitocra spinipes. Ecotoxicological and Environmental Safety, v. 11, p. $127-143,1986$.

TISLER, T.; ZAGORC-KONCAN, J.; ROS, M.; COTMAN, M. Biodegradation and toxicity of wastewater from industry producing mineral fibres for thermal insulation. Chemosphere, v. 38, p. $1347-1352,1999$.

WAKE H. Oil refineries: a review of their ecological impacts on the aquatic environment. Estuarine Coast and Shelf Science, v. 62, p. $131-140,2005$. 